\title{
神経成長因子（NGF）の酵素免疫測定法
}

\section{古川 昭栄}

\section{はじめに}

神経栄養因子と呼ばれる一群の物質は神経細胞の分化, 成熟, 生存や機能維持に必須の因子であると考えられて いる. 神経成長因子（nerve growth factor: NGF）は 代表的な神経栄養因子であり，末梢では交感神経細胞や 知覚神経細胞, 中枢では前脳基底核コリン作動性神経細 胞に作用する(1). しかし近年, リンパ球, 白血球, マ クロファージ，肥満細胞など免疫系細胞の增殖や分化を 促進する作用が見い出され，神経系と免疫系をつなぐサ イトカインとしての役割が注目されてきている(2). 従っ て神経系, 免疫系を研究対象とする多くの研究で多かれ 少なかれ NGF との関連を念頭に置かざるを得ない状況 になってきており，NGF を定量する必要性が高まって きている.

本稿では最も信頼性が高く, 高感度な NGF の測定法 である酵素免疫測定法について述べる. 1983 年に筆者 らが初めて報告(3) して以来多数の变法が発表され(4 $\sim 8)$, NGF 研究の中心的手法として現在も広く用いら れている.

\section{I . NGF 測定の問題点}

マウス NGF 前駆体はシグナル配列を含む 307 個の アミノ酸からなる分泌型タンパク質である. 特異酵素に よるプロセッシングにより 118 個のアミノ酸から成る 分子量 13,259 の活性型分子となり二量体を形成する(1). NGF を定量する場合念頭に置かねばならないのは，1） 生理的な存在量が少ない，2）非生理的に高レベルで NGF を含む動物組織がある，3）NGF に構造が類似す

岐阜薬科大学分子生物学講座

（宁502 岥阜市三田洞東 5-6-1）

原稿受領日 : 1997 年 1 月 8 日

編集委員会依頼原稿
るファミリー因子が存在する，などである．生理機能に 関わる NGF は多くの末梢組織や神経組織にごく微量 （g 組織あたり $1 \mathrm{ng}$ 以下）しか存在しないので検出に は高感度なシステムが必要である. その一方で，2） マ ウス顎下腺, ウシ精液, 精襄, モルモット前立腺には生 理濃度の実に百万倍むの NGF が含まれておりこれといっ た生理的役割が見い出されないばかりか生理的な NGF を測定する障害になる，たとえばマウスの組織サンプル を調製するとき顎下腺にふれた八サミやピンセットを使 うだけで值が大きくなる. NGF の研究にマウスでなく ラットがよく用いられる理由はここにある.

近年 NGF とほぼ $50 \%$ のミノ酸配列ホモロジーを あつファミリー因子が見い出され（NGF を含めニュー ロトロフィンファミリーと総称される), NGF に対して 作製した抗体が必ずしも特異的とは言えない現状がある. 現在のところ脳由来神経栄養因子（brain-derived neurotrophic factor), ニューロトロフィン (neurotrophin)-3, NT-4, NT-5 が見つかっており, 別々の受容 体を介して生理的に独立して機能している $(9,10)$ ， し たがって個々の分子を区別して測定することが必要であ り BDNF，NT-3 の EIA 法も試みられている.

\section{II. 酵素免疫測定法による NGF の測定}

\section{1. 測定方法の特徵}

酵素免疫測定法は本稿では enzyme immunoassay を 略し EIA と呼ぶ. enzyme-linked immunosorbent assay, ELISA と称することも多い. ほとんど同義語であ る. 放射能を用いる radioimmunoassay と原理は同じ であるが, NGF の場合適正な条件で標識した酵素分子 はモルあたりの検出効率が放射能より高く, 高感度とな る. 固相化した十分量の抗体に試料中の抗原を結合した 後さらに酵素標識抗体を抗原に結合し, 最後に酵素活性 を定量する、いわゆる two-site EIA またはサンドイッ 
チ EIA と呼ばれるシステムである (図 1). タンパク質 など分子量の大きい分子の測定に用いられ, NGF の測 定に適している. NGF 分子に 2 個以上の抗体が結合す ることが測定の必須条件なので特異性が高く他のニュー ロトロフィンとの交差性はほとんど問題にならない. 筆 者らの系では組織抽出物中の NGF の分子サイズ, 等電 点はマウス顎下腺から精製された活性型 NGF と違いが なかったことから前駆体は認識せず活性型 NGF だけを 特異的に検出すると考えている(3).

\section{2. 準備するもの}

(1)抗 NGF 抗血清 : マウス顎下腺 NGF (3) を抗原と してウサギで作製する. 1 匹あたり $0.5 \mathrm{mg}$ の NGF を 含む生理溶液を等容量の Freund's complete adjuvand と乳濁し 3 週に 1 度皮下注射する. 3 4 回の追加免疫 で十分に抗体価が上昇する. 最終免疫から 1 週後に全 血液を採取する. 血清を小分けして $-80^{\circ} \mathrm{C} て ゙$ 保存する.

(2)抗体の調製：プレートに固相化する抗体（抗原結合 用）はプロテイン A カラムで精製した IgG を用いる. ビオチン標識抗体（抗原検出用）はアフィニティー精製 抗体を用いる (IgGより検出感度が 10 倍以上高い). アフィニティー精製抗体は, NGF を共有結合させた樹 脂カラムに抗 NGF 血清を通して樹脂に抗体を結合させ, 洗浄後, 抗体を酸性溶液で溶出した（樹脂メーカーの使 用説明書参照). 抗血清 $1 \mathrm{ml}$ から約 100-300 $\mu \mathrm{g}$ のアフィ
ニティー精製抗体が得られる. いずれの抗体す小分けし て $-80^{\circ} \mathrm{C}$ で保存する.

(3)ビオチン標識抗体 : 固相抗体に結合した抗原は標識 抗体で検出する. ペルオキシダーゼや $\beta$-ガラクトシダー ゼを標識した抗体が用いられてきたが, 近年アビジンビオチンの強い結合を利用した系が繁用されており筆者 らも現在この系を用いている. 少量の抗体を簡便にビオ チン化することで無駄なく再現性の高い標識抗体を作製 できる. 以下に作製方法を示す.

生理的リン酸緩衝液で透析したアフィニティー精製抗 体 $10 \mu \mathrm{g} \quad(100-500 \mu \mathrm{g} / \mathrm{ml})$ を反応チューブにとり, 使 用直前に dimethyl formamide に溶解した biotinyl- $\varepsilon$ aminocaproic acid N-hydroxysuccinimide ester (ベー リンガー山之内社製）を $10 \mu \mathrm{g}(10 \mathrm{mg} / \mathrm{ml})$ 添加し軽 く振り混ぜる.このとき dimethyl formamide 液が抗 体溶液の $10 \%$ を超えないように注意する（抗体が沈澱 する). $30^{\circ} \mathrm{C}$ で 2 時間反応させた後, $0.1 \mathrm{ml}$ の $1 \mathrm{M}$ Tris- $\mathrm{HCl}$ 緩衝液を加えて反応を止め, 牛血清アルブミ ン $(1 \mathrm{mg} / \mathrm{ml})$, 防腐用の $0.02 \% \mathrm{NaN}_{3}$ を含む $0.05 \mathrm{M}$ $\mathrm{Tris}-\mathrm{HCl}$ 緩衝液を加え $4{ }^{\circ} \mathrm{C}$ で保存する。数カ月間は使 用可能である.

(4)組織 NGF の抽出: NGF は塩基性タンパク質 （pI=9.3）であり物質表面に吸着しやすく組織から回収 しにくい. 抽出効率を高めるため高タンパク質, 強イオ

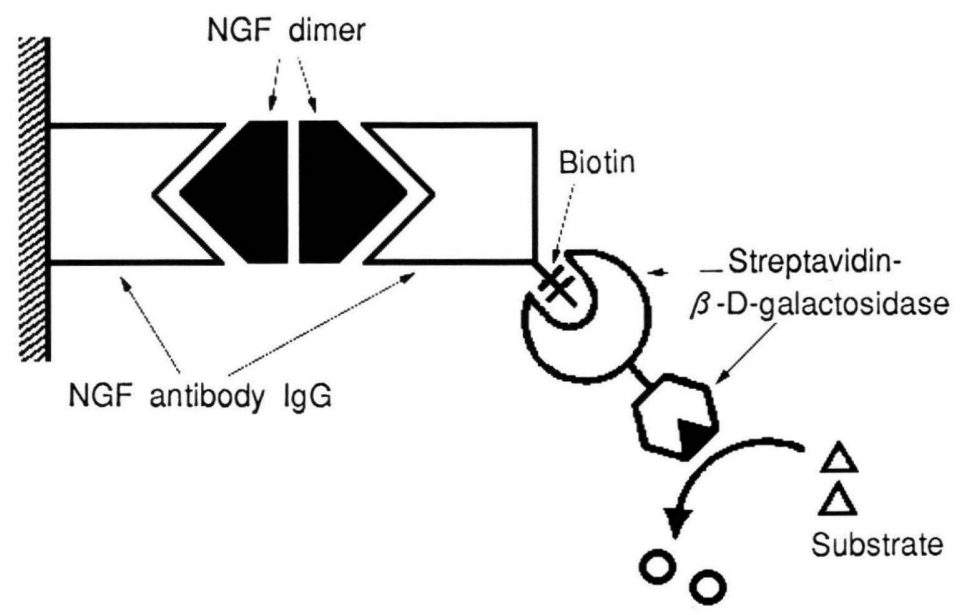

Fluorescence

Fig. 1 Principle of a two-site enzyme immunoassay for mouse nerve growth factor. 
ン強度の抽出用緩衝液として $2 \%$ 牛血清アルブミン, 1 unit $/ \mathrm{ml}$ の aprotinin（Sigma 社製, serine proteinase inhibitor), $1 \mathrm{M} \mathrm{NaCl}, 2 \mathrm{mM}$ EDTA，を含む $0.1 \mathrm{M}$ Tris- $\mathrm{HCl}$ 緩衝液, $\mathrm{pH} 7.6$ （pH は最後に合わせる）を用 いる. 組織と抽出用緩衝液の比率も回収率に影響する. 組織の比率が 10\%を越えると急に回収率が悪くなるの で比率を下げたいところであるが組織中の NGF が少量 であるため比率を下げすぎると NGF 濃度が検出感度以 下になってしまう。筆者らは通常 5\%(W/V) でホモ ジナイズしている．つまり組織の重さが $10 \mathrm{mg}$ のとき は $190 \mu 1$ の抽出用緩衝液を加える. 液量は 0.2-1 ml の スケールに組織量を調節しソニケーターの微小チップを その中に沈めてホモジナイズする，破砕時間，強度，パ ルス数が回収率とバックグラウンド值に影響するので事 前に適正な条件を調べ，さらにサンプル間で破砕条件を 一定に保つ必要がある. 10 万 $\times \mathrm{g}$ で 10 分間遠心し上 澄を集めて EIA に供する. 回収率を一定に保つため破 砕から遠心までの時間を一定にする.

(5)NGF の回収率：NGF 測定の最も大きな障害は組 織をホモジナイズするとき NGF 分子が破砕組織片に吸 着され溶液中に回収されなくなることである.そこで一 定量の NGF を添加した抽出液と NGF 無添加の抽出液 を用意し,この 2 種類の抽出液で同じ組織をホモジナ イズしそれぞれ NGF 濃度を EIA によって求める。 あ し添加した NGF が 100\%抽出液に回収されれば NGF 濃度の差は添加した NGF 量に等しくなるはずである. 実際はその値より低くなるのでその差を添加量（濃度） で割りこれをみかけの回収率とする.すなわち添加した NGF と内因性の NGF が同じ挙動をすることを前提に している.70\%以上の回収率があれば実際の使用には 十分である.

(6)NGF 標準溶液 : サンプル（抽出緩衝液, 培養液な ど）と同じ液で NGF 標準液を作る。高濃度液（1 $\mu \mathrm{g} /$ $\mathrm{ml}$ ）を小分けして東結保存し使用時に希釈し $50 \mathrm{ng} / \mathrm{ml}$ とする.これを 3 倍段階希釈する.このとき希釈ごと に分注用チップを取り変える. NGF はチップに吸着さ れやすく, 同じチップで最後まで希釈すると低濃度領域 では計算よりはるかに高濃度となる，チップを取り変え ると理論值より低濃度になるがこの方が影響が少ない。 通常, $5.6 \mathrm{ng} / \mathrm{ml}$ から 12 段階の希釈サンプルを標準液 として用いる. EIA を施行しその結果, $2-7 \mathrm{pg} / \mathrm{ml}$ で有 意な蛍光強度の上昇があること, 高濃度 NGF 添加と NGF 無添加での蛍光強度の比が 100 倍以上あれば条件
設定は良好である.

\section{3. 操作方法}

(1)抗体の固相化 : プロテイン A カラムで精製した抗 体 IgG を $0.1 \mathrm{M}$ Tris- $\mathrm{HCl}$ 緩衝液, $\mathrm{pH} 7.6$ で $100 \mu \mathrm{g} / \mathrm{ml}$ に調製する. $\mathrm{NaN}_{3}$ を加え $4^{\circ} \mathrm{C}$ で保存する. 96 穴プレー ト(ファルコン社製 EIA 用, 製品番号 3910, U 字底) のウエルごとに $5 \mu 1$ ずつ滴状（ウエルの中央部）に置 く（multi dispense 機能のついた電動式マイクロピペッ トが便利)。パラフィルムで厳重にシールし 1 時間室温 に置く. 抗体を除き (回収して数回使用可能), 各ウェル に $0.1 \%$ 牛血清アルブミン, $0.4 \mathrm{M} \mathrm{NaCl}, 1 \mathrm{mM} \mathrm{MgCl}_{2}$, $0.02 \% \mathrm{NaN}_{3}$ を含む $0.1 \mathrm{M}$ Tris- $\mathrm{HCl}$ 緩衝液, $\mathrm{pH} 7.6$ （緩衝液 $\mathrm{A}$ と呼ぶ）を $150 \mu 1$ ずつ添加する。3 30 分静置 した後, 吸引除去し, $1 \%(\mathrm{v} / \mathrm{v})$ の牛乳を含む緩衝液 A $150 \mu 1$ を添加, 1 時間静置する. 牛乳の中に含まれる カゼインがよいブロッキング剤となる. 専用に市販され ているスキムミルクやブロックエースであよい，な扰 体のかわりに正常ウサギ IgG をコートしたウエル, ま たは抗体をコートしていないウェルをコントロールとし て同一プレート内に設定し抗体との非特異的シグナルを 算出できるようにする.

(2)サンプルの添加 : 抗体プレートからブロッキング液 を吸引除去し直ちに $20 \mu 1$ のサンプル液をウエルに添加 する. サンプル液の蒸発とウエルの乾燥をふせぐため迅 速にサンプルを添加する. あらかじめ別のプレート（抗 体処理無し）にサンプルを順序よく並べておきマルチチャ ンネルピペットで一気に抗体プレートに添加する（1 分 以内に終える). 実際の測定には 1 サンプルあたり $3 \sim 4$ 個の抗体コートウエルとコントロールウエルを設定する. 厳重にパラフィルムでシールし, 振とうしながら室温で 2 時間置く.

(3)プレートの洗浄：サンプルを吸引除去後, $150 \mu 1$ の緩衝液 A でウエルを 2 回洗浄する．プレートが乾燥 しないよう注意する. 以後の洗浄操作も同じ.

(4)ビオチン標識抗体の添加 : $1 \%$ 正常ウサギ血清を含 む緩衝液 A でビオチン標識抗体を希釈 (約 $10 \mathrm{ng} / \mathrm{ml}$ ) し, マルチチャンネルピペットを使って $20 \mu 1$ ずつウエ ルに添加する．バックグラウンド值の上昇を抑えるため $4{ }^{\circ} \mathrm{C}$ で $12 \sim 18$ 時間反応後, 緩衝液 $\mathrm{A}$ でウエルを 2 回洗 浄する.

(5)ストレプトアビジン- $\beta$-D-ガラクトシダーゼ : スト レプトアビジン標識 $\beta$-D-ガラクトシダーゼ（ベーリン ガー山之内社製，製品番号 13114220-02）を反応させ 
る. 緩衝液 A で 6000 倍に希釈し, $20 \mu 1$ ずつウエルに 添加する. 厳重にシールし室温で 1 時間反応させる. 反応後, ウエルを緩衝液 A で 2 回洗浄する.

(6) $\beta$-D-ガラクトシダーゼ活性の測定 : 緩衝液 $\mathrm{A}$ に 10 $\mu \mathrm{g} / \mathrm{ml}$ で溶解した $20 \mu 1$ の 4-メチルウンベリフェリル $\beta$-D-ガラクトシドを添加する. シールで遮光し室温で 約 5 時間反応させる. $100 \mu 1$ の $0.1 \mathrm{M}$ glycine- $\mathrm{NaOH}$ 緩衝液, $\mathrm{pH} 10.3$ を添加して反応を止める.

(7)蛍光強度の測定 : 生じた 4-メチルゥンベリフェロ ンの蛍光を, $360 \mathrm{~nm}$ の励起, $450 \mathrm{~nm}$ の蛍光波長で測 定する. 蛍光強度を NGF 濃度に対して両対数プロット

しこれを標準曲線としてサンプルの蛍光強度から $\mathrm{NGF}$ 濃度を算出する. 数 $\mathrm{pg}$ から数 $\mathrm{ng} / \mathrm{ml}$ の範囲で用量依 存的な蛍光強度の増加がみられる。

\section{4. 測定の実際}

(1)ラット脳内 NGF レベル：前脳基底核コリン作動性
神経細胞は海馬, 大脳皮質, 嗅球へ軸索投射している. これらの部位では活発に NGF が産生され受容体を介す るエンドサイトーシスで軸索内に取り込まれ細胞体へ逆 行輸送されている. 成熟ラット脳では海馬, 大脳皮質, 嗅球に高レベルが, 前脳基底核でも中程度に NGF が検 出される(11）(図 2). しかし NGF はその他の脳部位 にも存在するので前脳基底核コリン作動性神経細胞だけ に作用する因子ではないと考えられる(12). マウス， スナネズミの脳でも基本的には類似の脳内分布を示す. 抗原性の違いはマウス(13), ラット，スナネズミ(14) 間ではほとんど問題にならないが，ウサギ，ヒトでは最 大結合量の低下, 検出感度の低下が認められる. 多少感 度は低くなるがヒト NGF（リコンビナント：市販品） を標準品とし，マウス NGF の EIA 系でヒト NGF を定 量することが可能である.

(2)神経損傷に伴う坐骨神経内 NGF レベルの変化 :

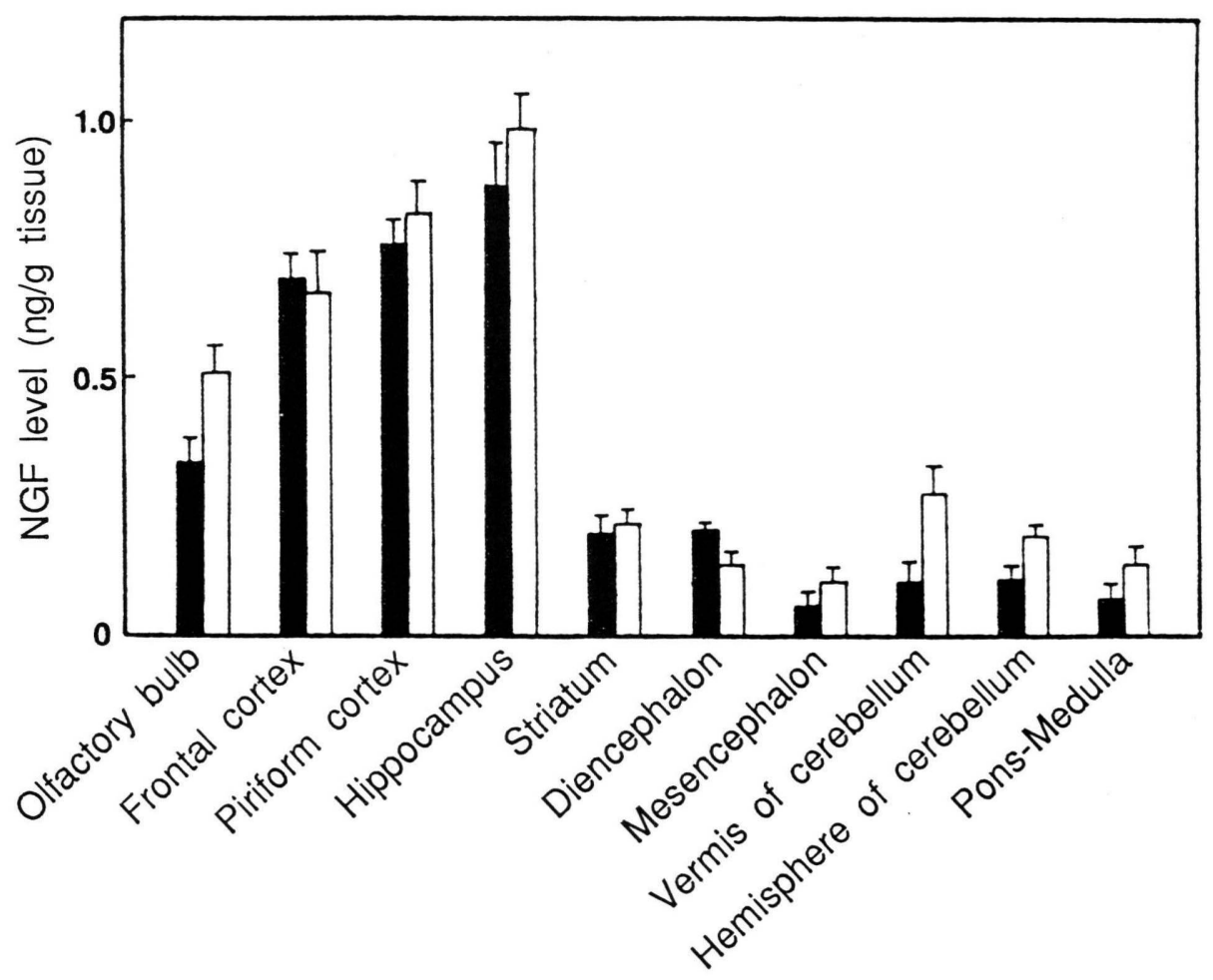

Fig. 2 NGF level in various brain regions. Various brain regions from 3-week old Wistar rats (male, closed box; female, open box; $n=5$ ) were assayed for their NGF content. The values represent the mean \pm S.E. of 5 expeiments. The values for the single experiment were determined in triplicate. 
末梢では交感, 侵害刺激伝達性知覚神経細胞が NGF 依存性である.NGF はこれらの神経細胞軸索投射領域 で合成され細胞体へと能動輸送される，坐骨神経には知 覚神経線維が含まれ末梢から中枢側へ輸送されている.

ラット坐骨神経を切断し神経内 NGF を経時的に測定す ると（図 3）まず 1 日後, 切断末梢端に著しいレベル増 加が観察される. 逆行性輸送は 20〜 $40 \mathrm{~cm} /$ 日のスピー ドがあり神経切断後もしばらくは機能するので, 輸送中
の NGF が行き場を失い断端に蓄積したと考えられる (15).ささらに時間がたつとこのピークは低くなるが末 梢側神経全体が高レベル化する．このとき末梢側はワー ラー変性に陥り, 浸潤マクロファージがインターロイキ ン-1 を分泌し神経内の線維芽細胞に作用して NGF 産生 を促進することを反映している，坐骨神経組織は小さく, NGF レベルあ高くないがこの実験では凍結・融解を繰 り返して効率よくNGF を抽出した。筆者らの EIA 系
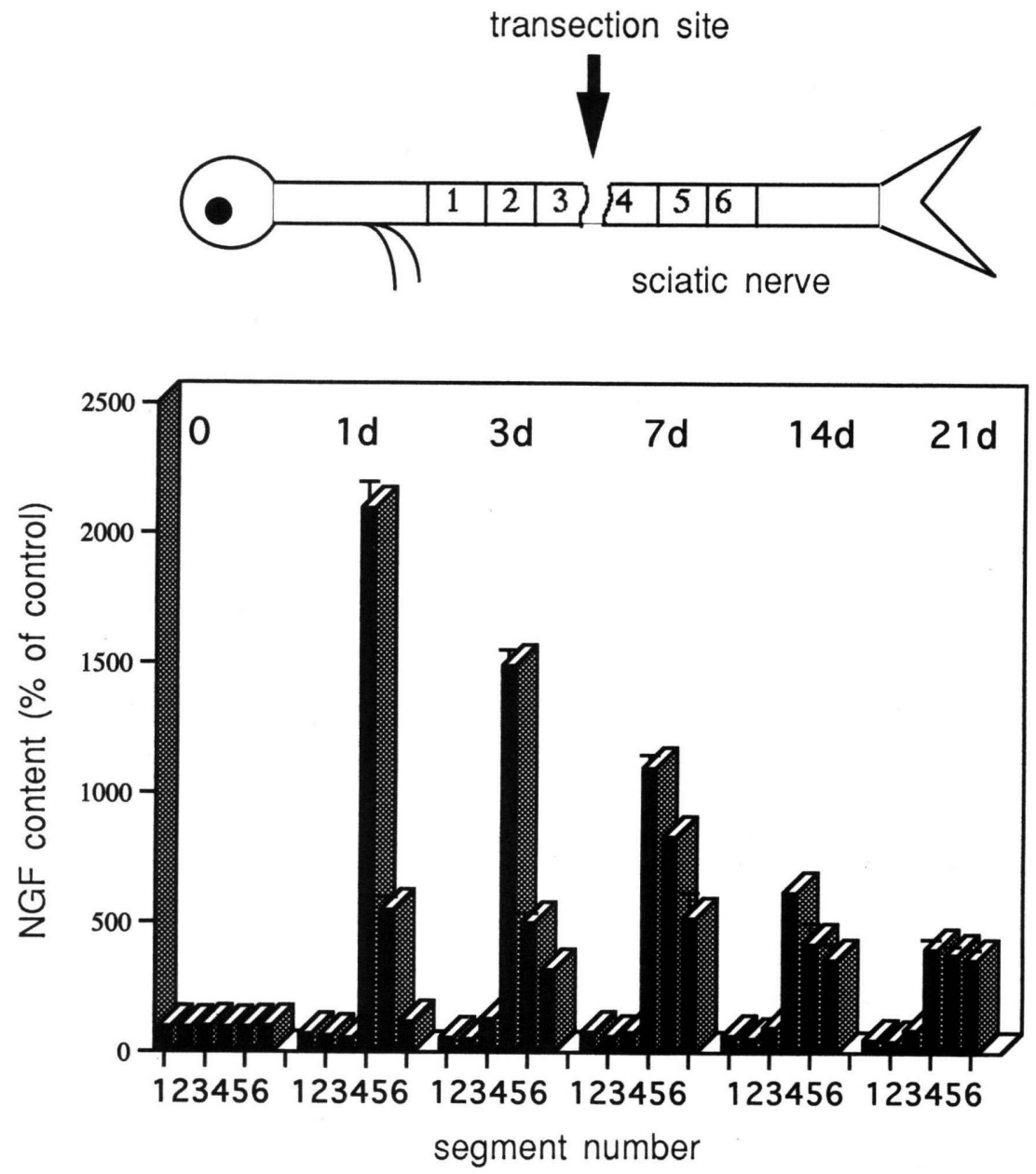

Fig. 3 Time courses of NGF level in the sciatic nerve after transection. The site of transection was between segments 3 and 4. Contralateral level of NGF $(733.0 \pm 26.0 \mathrm{pg} / \mathrm{g}$ tissue weight, $\mathrm{n}=5)$, which remained unchanged during the experiments, is indicated as $100 \%$. The given values represent the mean \pm S.E. of 5 experiments. The values for the single experiment were determined in triplicate. 
は少量のサンプルですむことが特徴の一つである.

(3)培養細胞による NGF の産生, 分泌とその促進物質 :

筆者らは高感度 EIA を使って線維芽細胞, シュワン 細胞, アストロサイトなどの非神経細胞が培養下で NGF を産生・分泌することを明らかにした(16)。最も 産生能の高い線維芽細胞でむ 1 日の NGF 分泌量は培養 液中に数 $\mathrm{ng} / \mathrm{ml}$ であるが容易に検出できる. 細胞内に むNGF が含まれているが 1 日の分泌量の $1 \%$ 程度に過 ぎなかった. 合成された NGF は速やかに細胞外へ分泌 されることを示している. さらにNGF 産生は細胞増殖 依存性であることや, いくつかの低分子化合物が NGF 産生を促進する作用を持つことを見い出している(16).

5. 市販されている測定用試薬, 抗体について

本稿では筆者らの EIA システムを紹介したが市販の 抗体を用いて EIA を組むこともできる. 抗マウス NGF モノクローナル抗体とその $\beta$-ガラクトシダーゼ標識品 がベーリンガー山之内から市販されている. EIA のプ ロトコールも添付されている. その他, 抗 NGF ポリク ローナル抗血清む市販されているが EIA に使えるかど うかは実際に系を組んでみなければわからない，この場 合は特異性のチェックも必要であろう。

\section{おわりに}

生物活性を指標とした NGF 測定法も古くから行われ ている. NGF に応答する神経組織や神経細胞を培養し 生存細胞数や突起の形成などを指標として評価する. PC - 12 細胞, 交感, 知覚神経細胞などが用いられてき たが厳密にはNGF だけに応答する神経細胞は存在しな いので特異性が問題になる. NGF に応答しない線維芽 細胞などに NGF の高親和性受容体 TrkA を強制発現さ せ NGF の作用で増殖するようにした細胞を用いる方法 ああるが, 特異性, 定量的評価ができる点, 高感度であ る点など, 現状ではEIA系が優っていると言える.し かし EIA で測定しているのはNGF の免疫交差活性で あり生物活性の有無は判断できない. 生物活性評価法と EIA 系の両方を用いて相互の欠点を補いながら測定を 進めることが最も現実的と思われる.

\section{文献}

1）林 恭三, 古川昭栄 : nerve growth factor. 細胞 成長因子, 日本組織培養学会編, pp 8-20, 朝倉書店, 東京 (1984)

2) 古川昭栄, 古川美子 : 神経成長因子 (NGF) - 神経
系と免疫系をつなぐサイトカイン分子一，神経精神 薬理 18, 807-813 (1996)

3) Furukawa S, Kamo I, Akazawa S, Furukawa Y, Satoyoshi E, Itoh K and Hayashi K: A highly sensitive enzyme immunoassay for mouse beta nerve growth factor. J Neurochem 40, 734-744 (1983)

4) Korsching $S$ and Thoenen H: Nerve growth factor in sympathetic ganglia and corresponding target organs of the rat. Correlation with density of sympathetic innervation. Proc Natl Acad Sci USA 80, 3513-3516 (1983)

5) Weskamp G and Otten U: An enzyme-linked immunoassay for nerve growth factor (NGF): a tool for studying regulatory mechanisms involved in NGF production in brain and in peripheral tissues. J Neurochem 48, 1779-1786 (1987)

6) Ayer-LeLievre C, Olson L, Ebendal T, Hallbook F and Persson H: Nerve growth factor mRNA and protein in the testis and epididymis of mouse and rat. Proc Natl Acad Sci USA 85, 2628-2632 (1988)

7) Katoh-Semba R, Semba R, Kashiwamata S and Kato K: Sex-dependent and sex-independent distribution of the beta-subunit of nerve growth factor in the central nervous and peripheral tissues of mice. J Neurochem 52, 1559-1565 (1989)

8) Kaechi K, Furukawa Y, Ikegami R, Nakamura N, Omae F, Hashimoto Y, Hayashi K and Furukawa S: Pharmacological induction of physiologically active nerve growth factor in rat peripheral nervous system. J Pharmacol Exp Ther 264, 321326 (1993)

9）古川昭栄：ニューロトロフィンと神経病巣修復. 神 経研究の進歩 39, 957-965 (1995)

10）古川美子, 古川昭栄 : NGF. 細胞増殖因子, 黒木 登志夫編集, pp 102-119, メディカルレビュ一, 東 京 (1995)

11) Hashimoto $Y$, Furukawa $S$, Omae F, Miyama $Y$ and Hayashi K: Correlative regulation of nerve growth factor level and choline acetyltransferase activity by thyroxine in particular regions of infant rat brain. J Neurochem 63, 326-332 (1994)

12) Nishio T, Akiguchi I and Furukawa S: Detailed distribution of nerve growth factor in rat brain determine by a highly sensitive enzyme immunoassay. Exp Neurol 116, 76-84 (1992)

13) Matsui K, Furukawa S, Shibasaki $\mathrm{H}$ and Kikuchi $\mathrm{T}$ : Reduction of nerve growth factor level in the brain of genetically ataxic mice (weaver, reeler). FEBS Lett 276, 78-80 (1990)

14) Hashimoto $Y$, Kawatsura H, Shiga $Y$, Furukawa $\mathrm{S}$ and Shigeno T: Significance of nerve growth factor content levels after forebrain ischemia in 
gerbil. Neurosci Lett 139, 45-46 (1992)

15) Ishikawa R, Nishikori K, Furukawa Y, Hayashi K and Furukawa S: Lesion-induced reduction of acidic fibroblast growth factor level in the distal part of rat sciatic nerve. Neurosci Lett 135, 113116 (1992)
16) Furukawa $S$ and Furukawa $Y$ : Nerve growth factor synthesis and its regulatory mechanisms: An approach to therapeutic induction of nerve growth factor synthesis. Cerebrovasc Brain Metab Rev 2, 328-344 (1990)

\begin{abstract}
A sensitive two-site (sandwich) enzyme immunoassay system for measuring nerve growth factor (NGF). Shoei FURUKAWA (Department of Molecular Biology, Gifu Pharmaceutical University, Mitahora-Higashi, Gifu 502, Japan). Folia Pharmacol. Jpn. 109, 235 241 (1997) Nerve growth factor (NGF) is a prototype of neurotrophin family neurotrophic factors that have nearly 50\% amino acid sequence homology with each other. NGF is known to support survival and stimulate differentiation of sympathetic and neural crest-derived some sensory neurons in the peripheral nervous system and the basal forebrain cholinergic neurons in the central nervous system. Recent investigations have expanded NGF action to much wider cell populations than previously known. Namely, NGF stimulates differentiation and/or proliferation of immune cells including lymphocytes, leucocytes and mast cells. These findings suggest important roles of NGF in the crosstalk between the nervous system and immune system. Therefore, a practical and sensitive method to quantify physiological NGF is in great demand. We developed a sensitive twosite enzyme immunoassay (EIA) system for mouse NGF, based on the sandwiching of the antigen between anti-mouse NGF antibody IgG coated to a plastic plate and biotinylated-anti-NGF antibody. Avidin- $\beta$-D-galactosidase was then bound to biotines, and galactosidase activity was determined fluorometrically. This method is simple, rapid and sensitive. Purified NGF is detectable at a concentration as low as a few $\mathrm{pg} / \mathrm{ml}$, which is enough to detect physiological NGF in various tissues and NGF secreted from cultured non-neuronal cells such as fibroblasts, astrocytes and Schwann cells.
\end{abstract}

著者プロフィール

古川 昭栄（ふるかわしょうえい）

$\diamond$ 岐阜薬科大学分子生物学講座. 教授. 薬学博士 (京都大学). $\diamond 1972$ 年京都大学農学部 卒業, '79 年京都大学大学院薬学研究科博士課程所定単位取得退学, '81 年国立武蔵療養所 神経センター研究員, 京都大学薬学博士, ' 86 年国立精神・神経センター免疫研究部室長, '90 年岐阜薬科大学分子生物学講座助教授, '95 年同 教授, 現在に至る. $\diamond$ 脳での産生調 節の観点から NGF ファミリー神経栄養因子の脳における機能を明らかにする．現在，脳 構築過程, 神経細胞死や高次脳機能との関連に興味をむっている. 趣味 : 天体観望と天

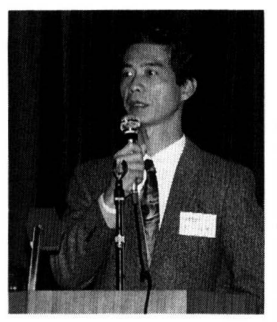
体望遠鏡のウィンドウショッピング. ○主な著書 : (1)老化のメカニズムと制御（分担執筆）, 藤本大三郎編集, アイピーシー社. (2)生物学的精神医学シリーズ, 痴呆の生物学 (分担執筆), 日本生物学的精神医学会, 三好功峰, 前田潔編, 学会出版センター. (3)細胞增殖因子 (分担執筆) 黒木登志夫編, メジカルレビュー社. 